\title{
Effect of NPK Fertilization Strategies on Growth, Yield, Nutrient Use Efficiency and Economic Benefits of Relay Intercropped Wheat in Cotton
}

\author{
Ali Zohaib ${ }^{1 *}$, Habib Ullah', Shakeel Ahmad Anjum², Tahira Tabassum², Muzzammil Hussain ${ }^{1}$, Mohsin \\ Nawaz $^{3}$, Ghulam Abbas ${ }^{4}$ and Sohail Irshad ${ }^{5}$
}

${ }^{1}$ Adaptive Research Farm, Gujranwala 52250, Pakistan; ${ }^{2}$ Department of Biology, Faculty of life Sciences, University of Okara, Okara 56300, Pakistan; ${ }^{3}$ College of Agriculture, Hainan University, Haikou 570228, China; ${ }^{4}$ Agronomic Research Institute, Ayub Agricultural Research Institute, Faisalabad 38000, Pakistan; ${ }^{5}$ Inservice Agricultural Training Institute, Rabim Yar Khan, 64200, Pakistan.

Abstract | Crop nutrient requirements vary in sole/mono and multiple cropping systems indicating the need for optimization of fertilization programs. This 2-years study was performed to investigate the influence of different strategies related to NPK fertilization timing viz. $\mathrm{T}_{1}$ (control, no NPK application), $\mathrm{T}_{2}$ (all $\mathrm{PK}$ at sowing, $1 / 2 \mathrm{~N}$ at tillering and $1 / 2$ at booting), $\mathrm{T}_{3}\left(1 / 2 \mathrm{PK}\right.$ at sowing, $1 / 2 \mathrm{NPK}$ at tillering and $1 / 2 \mathrm{~N}$ at booting), $\mathrm{T}_{4}$ (all PK at sowing, $1 / 2 \mathrm{~N}$ at sowing and $1 / 2$ at tillering), $\mathrm{T}_{5}$ (all $\mathrm{PK}$ at tillering, $1 / 2 \mathrm{~N}$ at tillering and $1 / 2$ at booting), $\mathrm{T}_{6}$ (all PK at tillering and $\mathrm{N}$ at booting) and $\mathrm{T}_{7}$ (all NPK at sowing) on growth, yield, agronomic nutrient use efficiency of nitrogen $\left(\mathrm{NUE}_{\mathrm{A}}\right)$ and economic benefits of relay-intercropped wheat in cotton. Fertilization timing significantly affected growth, yield and $\mathrm{NUE}_{\mathrm{A}}$ of wheat. Application of $\mathrm{T}_{4}$ (all PK at sowing, ${ }^{1 / 2} \mathrm{~N}$ at sowing and $1 / 2$ at tillering) caused maximum improvement in plant height, fertile tillers, grains per spike, biological yield, grain yield and $\mathrm{NUE}_{\mathrm{A}}$. Economic analysis also manifested that the greatest net returns and benefit cost ratio $(\mathrm{BCR})$ were obtained by same NPK application timing (i.e. $\mathrm{T}_{4}$ ). In conclusion, fertilization timing substantially affected the yield, $\mathrm{NUE}_{\mathrm{A}}$ and economic benefits of relay intercropped wheat in cotton; and application of $1 / 2 \mathrm{~N}$ and all $\mathrm{PK}$ at sowing and $1 / 2 \mathrm{~N}$ at tillering was most appropriate option.

Received | March 29, 2020; Accepted | December 14, 2020; Published | February 08, 2021

*Correspondence | Ali Zohaib, Adaptive Research Farm, Gujranwala 52250, Pakistan; Email: alizohaib208@gmail.com

Citation | Zohaib, A., H. Ullah, S.A. Anjum, T. Tabassum, M. Hussain, M. Nawaz, G. Abbas and S. Irshad. 2021. Effect of NPK fertilization strategies on growth, yield, nutrient use efficiency and economic benefits of relay intercropped wheat in cotton. Pakistan Journal of Agricultural Research, 34(1): 49-57.

DOI | http://dx.doi.org/10.17582/journal.pjar/2021/34.1.49.57

Keywords | Benefit cost ratio, Cotton-wheat relay intercropping, NPK fertilization timing, Nutrient use efficiency, Yield

\section{Introduction}

$\mathrm{I}$ n cotton-wheat cropping system, the food security is ensured altogether with economics by supplying wheat which is used as staple food in many countries of world and export earnings attained from cotton. It ensures higher total output because it fulfills necessities of the farmers to produce cotton as profitable cash crop and wheat as food crop to assure food supply (Smith and Varvil, 1982; Zhang et al., 2007, 2008a).

In cotton-wheat cropping system, wheat is usually grown following cotton; there is an overlay of a period comprising of approximately 20-30 days between wheat sowing in November and cotton harvesting in November-December. The successive planting of wheat following cotton harvesting is usually associated 
with several problems such as late sowing, meager crop stands, more weeds and poor yield because of adverse climatic circumstances (high temperature at grain formation, wind and rain at harvest) (Amanullah et al., 2000; Ugarte et al., 2007). Relay intercropping of wheat in cotton provides a better management alternative to combat the problem of late sowing of wheat (Khan and Khaliq, 2005). Moreover, Buttar et al. (2013) described that relay intercropped wheat in cotton produced significantly higher economic returns than conventionally sown wheat. Relay intercropping resulted in enhanced wheat yield (54\%), decreased tillage cost (98\%), increased cotton yield (15\%) and profit (32\%).

Aside from taking the benefit of sowing wheat at proper time better utilization and recovery of applied nutrients to the crops looks another benefit in relay intercropping system (Nielsen et al., 2001; Zhang et al., 2004). However, Willey (1990) proposed that intercropping system could improve nutrient catch up through absorption of nutrients which might have leached in a monoculture. Resultantly the intercrops may exhibit more demands on soil for nutrients and hence, in long run, yield advantages attained in intercropping system may have to be remunerated with decreased NUE and higher demand for fertilizer inputs. Nutrient use efficiency is used as measure to determine the nutrients used per unit yield produced. This shows that proper management of plant nutrition is quite essential for improving NUE in intercropping system. In this context the fertilization timing is of utmost importance (Sankaran et al., 2005) to acquire and sustain enhanced NUE in cotton-wheat relay intercropping system with minimum nutrient losses.

It is well known that proper fertilization timing is essential for gaining maximum yield, nutrient use efficiency and economic benefits with minimum nutrient losses (Mengel and Kirkby, 2001). Fertilizer application timing greatly impacts upon crop response to applied fertilizer since requirement of crop plants varies greatly during various growth phases (Abbasi et al., 2013). As in relay intercropping the wheat is sown when the cotton crop is at maturity and the wheat have to start its life cycle so wise use of fertilizers at proper time is necessary for improved growth and crop yield of wheat with minimum nutrient losses. It has been perceived that demand of the crop for nutrients in intercropping system may change over time that might result in decreased yield and NUE
(Zhang et al., 2008b).

Although numerous studies have revealed benefits of proper fertilization timing in sole/mono cropping of wheat (Singh and Sharma, 2001; Alam et al., 2002; Woolfolk et al., 2002; Akram et al., 2012; Haile et al., 2012); nonetheless, very little is known whether the fertilization timing is equally beneficial for wheat in relay intercropping system to obtain maximum yield and NUE with minimum nutrient inputs and losses. It was hypothesized that NPK application timing may affect the growth, yield, $\mathrm{NUE}_{\mathrm{A}}$ and economic benefits of relay intercropped wheat in cotton. The present study was therefore conducted to assess the effect of NPK fertilization timing for relay intercropped wheat in cotton for getting better yield and considerable improvements in $\mathrm{NUE}_{\mathrm{A}}$ in this system.

\section{Materials and Methods}

\section{Experimental details}

This study was accomplished at Agronomy Research Area, University of Agriculture, Faisalabad, Pakistan (latitude $31^{\circ} 26^{\prime} \mathrm{N}$ and $73^{\circ} 06^{\prime} \mathrm{E}$, altitude $185 \mathrm{~m}$ above mean sea level) in 2012-13 and 2013-14. The study was comprised of two phases. In first phase, cotton was sown on beds with the help of dibbler in last week of May during both the years. Cotton variety $\mathrm{MNH}-$ 886 was used in this study. Seed rate of $25 \mathrm{~kg} \mathrm{ha}^{-1}$ was used and sowing was done keeping the inter- and intra-row spacing of $75 \mathrm{~cm} \times 25 \mathrm{~cm}$. Thinning was done at four leaf stage to maintain plant population. Fertilizers (200-110-100 kg NPK ha ${ }^{-1}$ ) were applied as urea, triple super phosphate and sulfate of potash having $46 \% \mathrm{~N}, 46 \% \mathrm{P}_{2} \mathrm{O}_{5}$ and $50 \% \mathrm{~K}_{2} \mathrm{O}$, respectively. One third of $\mathrm{N}$ and whole $\mathrm{PK}$ were applied at sowing while application of remaining $\mathrm{N}$ was accomplished at squaring and flowering. In all 8 irrigations were applied during whole period of crop growth. Plant protection measures were applied according to expert recommendations.

In second phase, wheat was sown in standing cotton in first week of November during both the years. The experiment was comprised of different fertilizer application times. The treatments included $\mathrm{T}_{1}$ (control, no NPK application), $\mathrm{T}_{2}$ (all $\mathrm{PK}$ at sowing, $1 / 2 \mathrm{~N}$ at tillering and $1 / 2$ at booting), $\mathrm{T}_{3}(1 / 2 \mathrm{PK}$ at sowing, $1 / 2$ NPK at tillering and $1 / 2 \mathrm{~N}$ at booting), $\mathrm{T}_{4}$ (all PK at sowing, $1 / 2 \mathrm{~N}$ at sowing and $1 / 2$ at tillering), $\mathrm{T}_{5}$ (all $\mathrm{PK}$ at tillering, $1 / 2 \mathrm{~N}$ at tillering and $1 / 2$ at booting), $\mathrm{T}_{6}$ (all 
PK at tillering and $\mathrm{N}$ at booting) and $\mathrm{T}_{7}$ (all $\mathrm{NPK}$ at sowing). The total amount of fertilizers was applied @ 130-115-65 kg NPK ha ${ }^{-1}$, respectively, using the same sources as for cotton. Randomized complete block design was used to conduct the experiment with four replications. The net plot size was kept $8 \mathrm{~m} \times 3 \mathrm{~m}$. Physico-chemical characteristics of soil are given in Table 1 . The soil was sandy loam, having high $\mathrm{pH}$ and low in organic matter. The soil was medium in soil fertility level showing low levels of available NPK.

Wheat variety Punjab-11 was used for experiment and $150 \mathrm{~kg}$ seed ha-1 was used. Water soaked seed (12 hrs) was broadcasted in standing cotton. Cotton sticks were removed 40 days after the sowing of wheat. In all four irrigations were applied. Weeds were kept under economic threshold level by using herbicides. Crop was harvested at full maturity on $25^{\text {th }}$ April, 2013 and $30^{\text {th }}$ April, 2014. Weather data during 2012-13 and 2013-14 are presented in Figure 1.

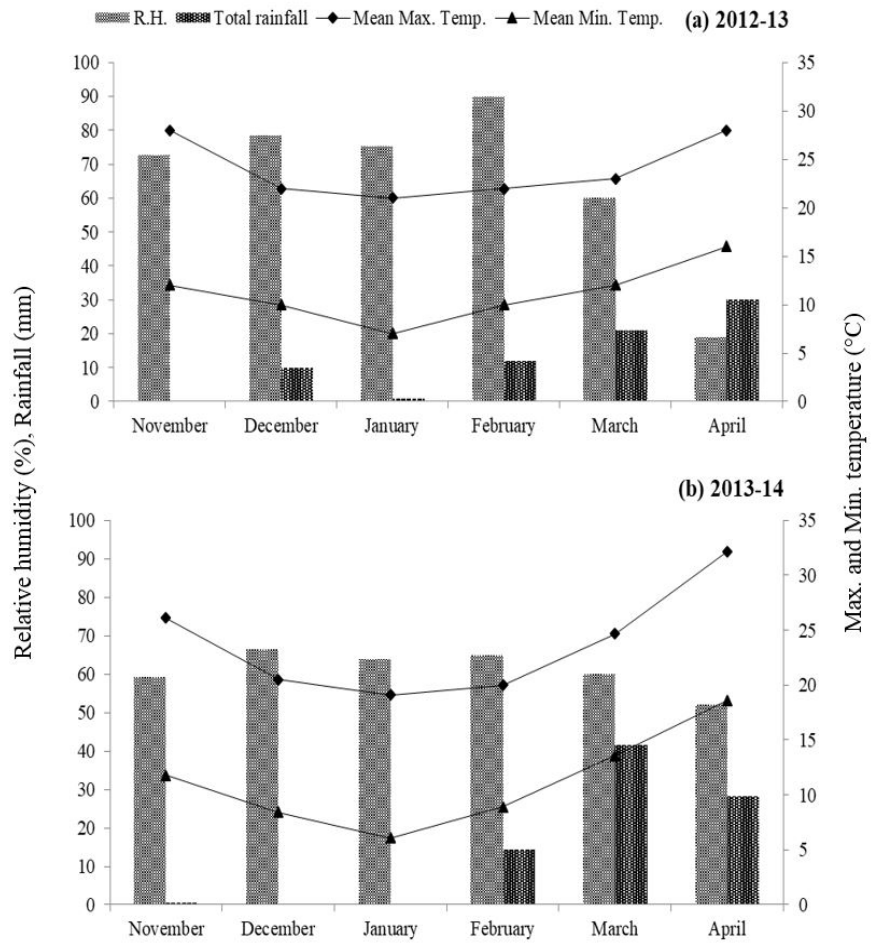

Figure 1: Weather conditions during wheat growing seasons of 2012-13 and 2013-14; Source: Agrometeorology Cell, Department of Crop Physiology, University of Agriculture, Faisalabad, Pakistan.

\section{Observations}

Data regarding emergence count (plants $\mathrm{m}^{-2}$ ), plant height $(\mathrm{cm})$, fertile tillers, spike length $(\mathrm{cm})$, spikelets and grains per spike, 1000-grain weight (g), and straw and grain yield $\left(\mathrm{t} \mathrm{ha}^{-1}\right)$ of wheat was recorded. Harvest index (HI) was calculated as;

$$
H I(\%)=\frac{\text { Grain yield }}{\text { Biological yield }} \times 100
$$

Agronomic nutrient use efficiency of nitrogen was calculated according to SSSP (1994):

$$
\mathrm{NUE}_{\mathrm{A}}=\frac{\text { Grain yield }_{\mathrm{F}}(\mathrm{kg})-\text { Grain yield }_{\mathrm{C}}(\mathrm{kg})}{\text { Fertilizer nutrient applied }(\mathrm{kg})}
$$

Where; $\mathrm{F}=$ fertilized crop; $\mathrm{C}=$ unfertilized crop (control).

$\begin{array}{ll}\text { Table 1: Physico-chemical properties of experimental soil. } \\ \text { Characteristics } & \text { Value } \\ \text { Textural class } & \text { Sandy loam } \\ \text { Organic matter } & 0.86 \% \\ \text { Electrical conductivity } & 2.48 \mathrm{dS} \mathrm{m}^{-1} \\ \mathrm{pH} & 8.0 \\ \text { Total nitrogen } & 0.04 \% \\ \text { Available phosphorous } & 8.82 \mathrm{mg} \mathrm{kg}^{-1} \\ \text { Extractable potassium } & 204 \mathrm{mg} \mathrm{kg}^{-1}\end{array}$

\section{Economic analysis}

Total cost, net returns and BCR was calculated using procedures of CIMMYT (1988). The total variable cost was calculated by summing up the cost of fertilizers, application charges, and harvesting and threshing charges. The harvesting and threshing charges were included in the variable cost because these charges were based upon the yield obtained from each treatment. The net returns were calculated using the formula; Net returns = gross Income - total cost, and benefit cost ratio (BCR) was calculated as;

$$
B C R=\frac{\text { Gross incom }}{\text { Total cost }}
$$

\section{Statistical analysis}

Data were statistically analyzed following the analysis of variance technique (Steel et al., 1997) and least significant difference (LSD) was used to compare treatments' means at 5\% probability level. There was a difference in precipitation (rainfall) with lower rainfall during 2012-13 relative to 2013-14; therefore, the interaction effect of year with NPK application timing on growth and yield traits, and $\mathrm{NUE}_{\mathrm{A}}$ was determined. However, the data showed non-significant interactions for NPK timing and year effects. Therefore, the main effects of NPK application timing and year are described. 
Results and Discussion

The NPK fertilization timing significantly improved growth and yield related attributes of wheat; furthermore, year effect differed significantly pertaining to these traits but the interaction of fertilization timexyear was non-significant for all the traits. However, emergence count was not affected significantly by either of NPK fertilization time, year and their interaction (Table 2). The plant height was enhanced due to application of NPK fertilizers and different fertilization timings produced differential plant height. The greatest plant height $(14 \%$ than control) was attained by $\mathrm{T}_{5}$ (all $\mathrm{PK}$ at tillering, $1 / 2 \mathrm{~N}$ at tillering and $1 / 2$ at booting) but $\mathrm{T}_{3}(1 / 2 \mathrm{PK}$ at sowing, $1 / 2$ $\mathrm{NPK}$ at tillering and $1 / 2 \mathrm{~N}$ at booting) and $\mathrm{T}_{4}$ (all $\mathrm{PK}$ at sowing, $1 / 2 \mathrm{~N}$ at sowing and $1 / 2$ at tillering) exhibited statistically similar results. Maximum fertile tillers (64\%), spike length (17\%), spikelets per spike (20\%) and grains per spike (15\%) were observed by $\mathrm{T}_{4}$ (all PK at sowing, $1 / 2 \mathrm{~N}$ at sowing and $1 / 2$ at tillering) when compared with control. However, statistically similar fertile tillers were obtained by $\mathrm{T}_{7}$ (all NPK at sowing); while, all NPK fertilization times (i.e. $\mathrm{T}_{2}-\mathrm{T}_{7}$ ) were statistically similar for spike length except $\mathrm{T}_{3}(1 / 2 \mathrm{PK}$ at sowing, $1 / 2 \mathrm{NPK}$ at tillering and $1 / 2 \mathrm{~N}$ at booting) which exhibited smaller spikes than others. Likewise, all these growths and yield related attributes were better in second year than first year (Table 3).

In present study, the emergence count did not affect significantly by NPK fertilization (Table 2) indicating that the process of emergence is independent of nutrient application or application timing in relay intercropping system of cotton wheat. Similarly, Akram et al. (2012) described that different times of NPK application didn't affect emergence in wheat. In this study, plant height and fertile tillers were

Table 2: Results of ANOVA for the effects of NPK fertilization timing, year and their interactions on growth, yield components, yield and NUE of relay intercropped wheat in cotton.

\begin{tabular}{|c|c|c|c|c|c|c|c|c|c|c|c|}
\hline Effect & $\begin{array}{l}\text { Emergence } \\
\text { count } \\
\text { (plants } \text { m }^{-2} \text { ) }\end{array}$ & $\begin{array}{l}\text { Plant } \\
\text { height } \\
\text { (cm) }\end{array}$ & $\begin{array}{l}\text { Fertile } \\
\text { tillers } \\
\mathbf{m}^{-2}\end{array}$ & $\begin{array}{l}\text { Spike } \\
\text { length } \\
(\mathrm{cm})\end{array}$ & $\begin{array}{l}\text { No. of } \\
\text { spikelets } \\
\text { per spike }\end{array}$ & $\begin{array}{l}\text { Grains } \\
\text { per } \\
\text { spike }\end{array}$ & $\begin{array}{l}1000 \text { grain } \\
\text { weight }(\mathrm{g})\end{array}$ & $\begin{array}{l}\text { Grain } \\
\text { yield (t/ } \\
\text { ha) }\end{array}$ & $\begin{array}{l}\text { Straw } \\
\text { yield } \\
(\mathrm{t} / \mathrm{ha})\end{array}$ & $\begin{array}{l}\text { Harvest } \\
\text { index } \\
(\%)\end{array}$ & $\mathrm{NUE}_{\mathrm{A}}$ \\
\hline Year $(Y)$ & $1.84^{\mathrm{ns}}$ & $6.19^{*}$ & $9.25^{* *}$ & $10.47^{* *}$ & $2.28^{\mathrm{ns}}$ & $5.28^{*}$ & $20.20^{* *}$ & $29.66^{* *}$ & $48.01^{\prime \prime}$ & $10.93^{* *}$ & $15.29^{* \prime}$ \\
\hline Fertilization timing $(\mathrm{T})$ & $0.52^{\mathrm{ns}}$ & $13.53^{* * *}$ & $26.49^{* * *}$ & $13.43^{\text {tw* }}$ & $36.92^{* *}$ & $8.39^{* *}$ & $3.66^{* *}$ & $31.61^{* *}$ & $178.7^{\mathrm{m}}$ & $0.35^{\mathrm{ns}}$ & $6.66^{* *}$ \\
\hline $\mathrm{T} \times \mathrm{Y}$ & $0.60^{\mathrm{ns}}$ & $0.85^{\mathrm{ns}}$ & $0.39^{\text {ns }}$ & $0.32^{\mathrm{ns}}$ & $1.83^{\text {ns }}$ & $0.23^{\text {ns }}$ & $0.68^{\mathrm{ns}}$ & $0.74^{\mathrm{ns}}$ & $5.83^{* \prime}$ & $0.74^{\mathrm{ns}}$ & $0.42^{\mathrm{ns}}$ \\
\hline
\end{tabular}

F values and significance levels (" $P<0.01, " P<0.05$ and ${ }^{n s} P \geq 0.05$ ).

Table 3: Effect of NPK fertilization timing on growth and yield related traits of relay intercropped wheat in cotton.

\begin{tabular}{|c|c|c|c|c|c|c|}
\hline Treatments & $\begin{array}{l}\text { Emergence count } \\
\left(\text { plants } m^{-2}\right)\end{array}$ & $\begin{array}{l}\text { Plant height } \\
\text { (cm) }\end{array}$ & $\begin{array}{l}\text { No. of fertile } \\
\text { tillers } \mathrm{m}^{-2}\end{array}$ & $\begin{array}{l}\text { Spike } \\
\text { length }(\mathrm{cm})\end{array}$ & $\begin{array}{l}\text { No. of spikelets per } \\
\text { spike }\end{array}$ & $\begin{array}{l}\text { No. of grains per } \\
\text { spike }\end{array}$ \\
\hline \multicolumn{7}{|c|}{ Fertilizer application timing $(\mathrm{T})$} \\
\hline $\mathrm{T}_{1}$ & $128 \mathrm{a}$ & $84.20 \mathrm{c}$ & $192 \mathrm{e}$ & $8.55 \mathrm{c}$ & $16.10 \mathrm{f}$ & $38.88 \mathrm{~b}$ \\
\hline $\mathrm{T}_{2}$ & $134 \mathrm{a}$ & $90.81 \mathrm{~b}$ & $238 \mathrm{~d}$ & $9.76 \mathrm{ab}$ & $17.96 \mathrm{~cd}$ & $43.25 \mathrm{a}$ \\
\hline $\mathrm{T}_{3}$ & $129 \mathrm{a}$ & $95.88 \mathrm{a}$ & $274 \mathrm{c}$ & $9.46 \mathrm{~b}$ & $17.42 \mathrm{e}$ & $43.00 \mathrm{a}$ \\
\hline $\mathrm{T}_{4}$ & $132 \mathrm{a}$ & $95.34 \mathrm{a}$ & $314 \mathrm{a}$ & $10.02 \mathrm{a}$ & $19.36 \mathrm{a}$ & $44.50 \mathrm{a}$ \\
\hline $\mathrm{T}_{5}$ & $131 \mathrm{a}$ & 96.13 a & $270 \mathrm{c}$ & $10.00 \mathrm{a}$ & $18.23 \mathrm{bc}$ & $44.00 \mathrm{a}$ \\
\hline $\mathrm{T}_{6}$ & $132 \mathrm{a}$ & $93.21 \mathrm{ab}$ & $283 \mathrm{bc}$ & $9.69 \mathrm{ab}$ & $17.50 \mathrm{de}$ & $43.00 \mathrm{a}$ \\
\hline $\mathrm{T}_{7}$ & $131 \mathrm{a}$ & $91.21 \mathrm{~b}$ & $298 \mathrm{ab}$ & $9.76 \mathrm{ab}$ & $18.58 \mathrm{~b}$ & $43.00 \mathrm{a}$ \\
\hline $\operatorname{LSD}(\mathrm{P} \leq 0.05)$ & $\mathrm{ns}$ & 3.27 & 22.6 & 0.39 & 0.48 & 1.82 \\
\hline \multicolumn{7}{|l|}{ Year } \\
\hline 2012-13 & $130 \mathrm{a}$ & $91.32 \mathrm{~b}$ & $258 \mathrm{~b}$ & $9.44 \mathrm{~b}$ & $17.78 \mathrm{a}$ & $42.32 \mathrm{~b}$ \\
\hline $2013-14$ & $133 \mathrm{a}$ & $93.48 \mathrm{a}$ & $276 \mathrm{a}$ & $9.78 \mathrm{a}$ & $17.98 \mathrm{a}$ & $43.42 \mathrm{a}$ \\
\hline $\operatorname{LSD}(\mathrm{P} \leq 0.05)$ & $\mathrm{ns}$ & 1.75 & 12.4 & 0.22 & $\mathrm{~ns}$ & 0.97 \\
\hline
\end{tabular}

Any two means not sharing a common letter are different significantly at $p \leq 0.05$; ns: non-significant; $T_{1}$ : control, no NPK application; $T_{2}$ all $P K$ at sowing, $1 / 2 N$ at tillering and $1 / 2$ at booting; $T_{3}: 1 / 2 P K$ at sowing, $1 / 2 N P K$ at tillering and $1 / 2 N$ at booting; $T_{4}$ all $P K$ at sowing, $1 / 2 N$ at sowing and $1 / 2$ at tillering; $T_{5}$ : all $P K$ at tillering, $1 / 2 N$ at tillering and $1 / 2$ at booting; $T_{6}$ : all $P K$ at tillering and $N$ at booting; $T_{7}$ : all $N P K$ at sowing. 
improved by NPK fertilization. Among different application timings the plant height and fertile tillers were enhanced by treatments which included the application of NPK at same time or $\mathrm{N}$ in splits including tillering stage e.g. $\mathrm{T}_{3}-\mathrm{T}_{5}$, and $\mathrm{T}_{4}$ as well as $\mathrm{T}_{7}$, respectively (Table 3 ). It has been known that in relay intercropping system of cotton-wheat the growth of intercrops is suppressed due to competition especially at the time when the preceding crop (cotton in this case) is at harvest (Zhang et al., 2007) and nutrient application especially $\mathrm{N}$ at or before this time can ensure the better growth of the intercrop (wheat in our case) (Zhang et al., 2008b). In our study, the wheat was at tillering stage when cotton was removed from the field and $\mathrm{N}$ application at this stage resulted in improved plant height and number of fertile tillers in particular. Malghani et al. (2010) revealed similar results that greater fertile tillers were produced by fertilized plots, as compared with control. Similarly, Rahman et al. (2011) stated that maximum fertile tillers of wheat were produced by $\mathrm{N}$ application at sowing and tillering in equal splits.

Present study showed better results pertaining to spike length by the treatments which included $\mathrm{N}$ application at tillering which employs that tillering stage is crucial regarding the application of $\mathrm{N}$ for better growth of plants as well as wheat inflorescence (Table 3). Nonetheless, present study results contradict to Basit et al. (2005) who observed that $\mathrm{N}$ application timing didn't affect spike length although improved by $\mathrm{N}$ fertilization as compared to control. The spikelets per spike were observed highest in $\mathrm{T}_{4}$ among different fertilization timings (Table 3) which was related to improved spike length by this treatment. However, Rajpar et al. (2006) described that $\mathrm{P}$ fertilizer application timing didn't affect the spikelets per spike. Likewise, grains per spike were increased by NPK fertilization but fertilization timings did not differ among each other (Table 3 ) and this is attributed to improved pollen viability due to proper crop nutrition (Mengel and Kirkby, 2001). Similarly, the Basit et al. (2005) stated that grains per spike were enhanced by $\mathrm{N}$ application; however, there was no difference among different fertilization timings. In our study, lesser wheat growth and development was observed during 2012-13 than 2013-14 (Table 3) which was associated with higher temperature during early growth stages during 2012-13 than 2013-14 (Figure 1).
The NPK fertilization timing and year significantly influenced 1000-grain weight, straw yield, grain yield and $\mathrm{NUE}_{\mathrm{A}}$ but interaction of fertilization timing $\times$ year was non-significant for these traits. However, harvest index was not influenced significantly by NPK fertilization timing but both the years differed significantly; while the interaction of fertilization timexyear was also non-significant (Table 2). The 1000-grain weight was improved by NPK fertilization and fertilization timings differed among each other. It was noticed that $\mathrm{T}_{2}$ (all the $\mathrm{PK}$ at sowing, $1 / 2 \mathrm{~N}$ at tillering and $1 / 2$ at booting) yielded heavier seeds i.e. $2.3 \%$ than control, however, $\mathrm{T}_{3}(1 / 2 \mathrm{PK}$ at sowing, $1 / 2 \mathrm{NPK}$ at tillering and $1 / 2 \mathrm{~N}$ at booting) gave statistically similar results. It was found that fertilizer application substantially improved yield and $\mathrm{NUE}_{\mathrm{A}}$ of wheat, when compared with control. Furthermore, the different fertilization timings differed among each other in this respect and $\mathrm{T}_{4}$ (all $\mathrm{PK}$ at sowing, $1 / 2 \mathrm{~N}$ at sowing and $1 / 2$ at tillering) showed maximum improvement in grain yield (107\% than control), straw yield (101\% than control), and $\mathrm{NUE}_{\mathrm{A}}$. It was observed that 1000-grain weight, straw yield, grain yield, harvest index as well as $\mathrm{NUE}_{\mathrm{A}}$ stood higher during 2013-14 as compared to 2012-13 (Table 4).

It was noticed that 1000-grain weight was enhanced by $\mathrm{T}_{2}$ and $\mathrm{T}_{3}$ in which the $\mathrm{PK}$ was applied at sowing and/or $1 / 2$ at sowing and $1 / 2$ at tillering while $\mathrm{N}$ was applied at tillering as well as booting stage (Table 4). However, it was also observed that $\mathrm{PK}$ was also applied at sowing in some other treatments in which $\mathrm{N}$ was not applied at booting stage such as $\mathrm{T}_{4}, \mathrm{~T}_{6}$ and $\mathrm{T}_{7}$ but the grain weight was less than $\mathrm{T}_{2}$ and $\mathrm{T}_{3}$. This makes the idea clear that to enhance the grain weight all PK application at sowing and $\mathrm{N}$ application at booting is necessary. Proper NPK nutrition is important for improving the grain weight through improved photosynthetic activities and better assimilates translocation (Barker and Pilbeam, 2007). Current study results are similar to Shah et al. (2011). Straw and grain yield was substantially improved by timing of NPK fertilization in this study. The greater grain yield was observed by $\mathrm{T}_{4}$ (Table 4 ) and it is ascribed to higher fertile tillers and grains per spike. Malghani et al. (2010) has reported similar findings. Likewise, increased straw yield is attributable to improved plant growth by NPK fertilization at proper time. However, Ros et al. (2003) reported non-significant influence of fertilizer application time on straw yield. The effect of NPK application timing on harvest index was 
non-significant; however, year effect was significant (Table 4). Increase in harvest index during 2013-14 is attributed to the more grain yield as well as total dry matter production. Current study results are similar to Yaseen et al. (2005) and Afridi et al. (2010).

The present study results showed better $\mathrm{NUE}_{\mathrm{A}}$ by NPK application, as compared with control, and fertilization at different times differed among each other. Higher $\mathrm{NUE}_{\mathrm{A}}$ was found by $\mathrm{T}_{4}$ (all PK at sowing, $1 / 2 \mathrm{~N}$ at sowing and $1 / 2$ at tillering) (Table 3 ). Highest $\mathrm{NUE}_{\mathrm{A}}$ by $\mathrm{T}_{4}$ shows that maximum nutrient uptake occurs when applied at proper time especially $\mathrm{N}$ when applied in splits due to reduction in its losses through leaching, denitrification, immobilization and/or volatilization (Barker and Pilbeam, 2007). Cassman et al. (2002) proposed that the nutrient application timing which matches the needs of crop is crucially essential and application of $\mathrm{N}$ in splits all through different stages of crop growth improves the NUE as compared to whole $\mathrm{N}$ fertilization at sowing, as observed in present study. Furthermore, previous study of Wen-Xia et al. (2007) confirms our argument that improper time of $\mathrm{N}$ application is the main reason of low NUE in the irrigated areas. In our study higher $\mathrm{NUE}_{\mathrm{A}}$ was noticed during second year (2013-14) which might be the result of less rainfall occurrence during early growth stages of wheat during 2013-14 which reduced the nutrient leaching losses especially $\mathrm{N}$ as compared to 2012-13 (Figure 1).

Table 4: Effect of NPK fertilization timing on yield related traits, yield and NUE of relay intercropped wheat in cotton.

$\begin{array}{llllll}\text { Treatments } & \begin{array}{l}\text { 1000-grain weight }(\mathbf{g}) \\ \text { Fertilizer application timing }(\mathrm{T})\end{array} & \text { Grain yield }\left(\mathbf{t ~ h a}^{-1}\right) & \text { Straw yield }\left(\mathbf{t ~ h a}^{-\mathbf{1}}\right) & \text { Harvest index (\%) } & \mathbf{N U E}_{\mathbf{A}} \\ \mathrm{T}_{1} & 42.66 \mathrm{bc} & 2.46 \mathrm{~d} & 3.84 \mathrm{e} & 38.69 \mathrm{a} & - \\ \mathrm{T}_{2} & 43.66 \mathrm{a} & 3.94 \mathrm{c} & 5.84 \mathrm{~d} & 38.67 \mathrm{a} & 11.36 \mathrm{c} \\ \mathrm{T}_{3} & 43.02 \mathrm{ab} & 4.29 \mathrm{bc} & 6.72 \mathrm{c} & 38.83 \mathrm{a} & 14.06 \mathrm{bc} \\ \mathrm{T}_{4} & 42.08 \mathrm{c} & 5.10 \mathrm{a} & 7.73 \mathrm{a} & 39.71 \mathrm{a} & 20.31 \mathrm{a} \\ \mathrm{T}_{5} & 42.58 \mathrm{bc} & 4.29 \mathrm{bc} & 6.80 \mathrm{c} & 38.08 \mathrm{a} & 14.06 \mathrm{bc} \\ \mathrm{T}_{6} & 42.26 \mathrm{bc} & 4.30 \mathrm{bc} & 6.83 \mathrm{c} & 38.45 \mathrm{a} & 14.10 \mathrm{bc} \\ \mathrm{T}_{7} & 41.88 \mathrm{c} & 4.66 \mathrm{~b} & 7.22 \mathrm{~b} & 39.09 \mathrm{a} & 16.89 \mathrm{~b} \\ \mathrm{LSD}(\mathrm{P} \leq 0.05) & 0.91 & 0.43 & 0.28 & n \mathrm{n} & 3.26 \\ \text { Year } & & & & & \\ 2012-13 & 42.06 \mathrm{~b} & 3.84 \mathrm{~b} & 6.18 \mathrm{~b} & 37.70 \mathrm{~b} & 11.35 \mathrm{~b} \\ 2013-14 & 43.13 \mathrm{a} & 4.44 \mathrm{a} & 6.68 \mathrm{a} & 39.87 \mathrm{a} & 14.45 \mathrm{a} \\ \mathrm{LSD}(\mathrm{P} \leq 0.05) & 0.48 & 0.23 & 0.15 & 1.32 & 1.88\end{array}$

Any two means not sharing a common letter are different significantly at $p \leq 0.05$; ns: non-significant; $N U E_{A}=$ Agronomic nutrient use efficiency; $T_{1}$ : control, no NPK application; $T_{2}$ : all $P K$ at sowing, $1 / 2 N$ at tillering and $1 / 2$ at booting; $T_{3}: 1 / 2 P K$ at sowing, $1 / 2 N P K$ at tillering and $1 / 2 N$ at booting; $T_{4}$ : all $P K$ at sowing, $1 / 2 N$ at sowing and $1 / 2$ at tillering; $T_{5}$ : all $P K$ at tillering, $1 / 2 N$ at tillering and $1 / 2$ at booting; $T_{6}$ : all $P K$ at tillering and $N$ at booting; $T_{7}$ : all $N P K$ at sowing.

Table 5: Effect of NPK fertilization timing on economic efficiency of relay intercropped wheat in cotton.

\begin{tabular}{|c|c|c|c|c|c|c|c|c|c|c|}
\hline \multirow{2}{*}{$\begin{array}{l}\text { Treat- } \\
\text { ments }\end{array}$} & \multicolumn{2}{|c|}{ Gross income (Rs. hä $\left.{ }^{-1}\right)$} & \multicolumn{2}{|c|}{ Variable cost $\left(\right.$ Rs. ha $\left.{ }^{-1}\right)$} & \multicolumn{2}{|c|}{ Total cost (Rs. ha $\left.{ }^{-1}\right)$} & \multicolumn{2}{|c|}{ Net returns (Rs. ha $\left.{ }^{-1}\right)$} & \multicolumn{2}{|c|}{ Benefit cost ratio } \\
\hline & 2012-13 & 2013-14 & $2012-13$ & 2013-14 & 2012-13 & 2013-14 & $2012-13$ & 2013-14 & 2012-13 & 2013-14 \\
\hline T1 & 90050 & 100881 & 9756 & 10560 & 73186 & 73990 & 16864 & 26891 & 1.23 & 1.36 \\
\hline $\mathrm{T} 2$ & 133140 & 169763 & 48267 & 52378 & 111697 & 115808 & 21443 & 53954 & 1.19 & 1.47 \\
\hline T3 & 149930 & 183519 & 49793 & 53739 & 113223 & 117169 & 36707 & 66349 & 1.32 & 1.57 \\
\hline $\mathrm{T} 4$ & 183140 & 206419 & 53226 & 55894 & 116656 & 119324 & 66484 & 87095 & 1.57 & 1.73 \\
\hline T5 & 149515 & 184896 & 49349 & 53596 & 112779 & 117026 & 36737 & 67870 & 1.33 & 1.58 \\
\hline T6 & 149165 & 185453 & 49060 & 53926 & 112490 & 117356 & 36675 & 68096 & 1.33 & 1.58 \\
\hline T7 & 167730 & 193163 & 51111 & 54274 & 114541 & 117704 & 53189 & 75459 & 1.46 & 1.64 \\
\hline
\end{tabular}

Total fixed cost $=$ Rs. 63430/-, $T_{1}$ : control, no NPK application; $T_{2}$ : all $P K$ at sowing, $1 / 2 N$ at tillering and $1 / 2$ at booting; $T_{3}: 1 / 2 P K$ at sowing; $1 / 2 N P K$ at tillering and $1 / 2 N$ at booting; $T_{4}$ all $P K$ at sowing, $1 / 2 N$ at sowing and $1 / 2$ at tillering; $T_{5}$ all $P K$ at tillering, $1 / 2 N$ at tillering and $1 / 2$ at booting; $T_{6}$ : all $P K$ at tillering and $N$ at booting; $T_{7}$ : all $N P K$ at sowing; note: the variable cost in $T_{1}$ : control (no fertilizer) includes the barvesting and threshing charges. 
Economic analysis revealed that the greatest net returns and $\mathrm{BCR}$ was obtained by $\mathrm{T}_{4}$ (all $\mathrm{PK}$ at sowing, $1 / 2 \mathrm{~N}$ at sowing and $1 / 2$ at tillering) during both the years; although the variable cost was also highest in $\mathrm{T} 4$ and it was followed by $\mathrm{T}_{7}$ (all NPK at sowing). Moreover, higher net returns and BCR was gained during second year (Table 5). Application of NPK at different times resulted in better economic efficiency by efficient utilization of nutrients and improving the crop yield, as compared with control (Table 5). Greater net returns and BCR were obtained by $\mathrm{T}_{4}$ during both the years (Table 5). Higher net returns and BCR by $\mathrm{T}_{4}$ were the resultant of higher yield which was obtained by the application of NPK and proper application time management. Furthermore, higher net returns during 2013-14 were obtained due to better yield during second year than first year. Niamatullah et al. (2011) reported improved economic efficiency by NPK fertilizers' application. Naveed et al. (2013) reported improved economic returns and $\mathrm{BCR}$ of dual purpose wheat by proper management of $\mathrm{N}$ application time.

\section{Conclusions and Recommendations}

The application of NPK fertilizers at different times significantly increased the yield and related attributes along with improving $\mathrm{NUE}_{\mathrm{A}}$ and economic efficiency. Moreover, $\mathrm{T}_{4}$ (all PK at sowing, $1 / 2 \mathrm{~N}$ at sowing and $1 / 2$ at tillering) proved the best as it gave greater fertile tillers, spike length and ultimately the grain yield. In conclusion, the fertilization timing impacts upon growth, yield and $\mathrm{NUE}_{\mathrm{A}}$ and proper fertilizer application timing is important to save scarce resources and enhance the net farm income in relay intercropped wheat in cotton.

\section{Novelty Statement}

Proper fertilization timing is essential for better productivity of wheat but information is lacking for relay intercropped wheat in cotton. This study was conducted to determine the effect of NPK fertilization timing on yield formation; economic benefits and nutrient use efficiency of $\mathrm{N}$ of relay intercropped wheat in cotton.

\section{Author's Contribution}

Ali Zohaib gave technical input during experimentation, prepared the write up and did overall management of article. Habib Ullah conducted experiment and collected data. Shakeel Ahmad Anjum supervised the study. Tahira Tabassum helped in literature review and conclusion. Muzzammil Hussain guided for experimentation. Mohsin Nawaz helped in data analysis. Ghulam Abbas collected literature. Sohail Irshad helped in abstract.

\section{Conflict of interest}

The authors have declared no conflict of interest.

\section{References}

Abbasi, M.K., M.M. Tahir and N. Rahim. 2013. Effect of $\mathrm{N}$ fertilizer source and timing on yield and $\mathrm{N}$ use efficiency of rainfed maize (Zea mays L.) in Kashmir-Pakistan. Geoderma, 195: 87-93. geoderma.2012.11.013

https://doi.org/10.1016/j.

Afridi, M.Z., M.T. Jan, M. Arif and A. Jan. 2010. Wheat yielding components response to different levels of fertilizer- $\mathrm{N}$ application time and decapitation stress. Sarhad J. Agric. 26(4): 499-506.

Akram, M., M. Ali, T. Mahmood, M.K. Munir, M. Saleem, M. Asla, M. Asif and K. Khakwani. 2012. Impact of NPK application time on the yield of wheat. Crop Environ. 3(1): 58-61.

Alam,S.M.,A.Latif and Z.Iqbal.2002. Wheat yield and phosphorus use efficiency as influenced by method of phosphorus and zinc application. Pak. J. Sci. Ind. Res. 45(2): 117-119.

Amanullah, J., H. Ijaz and M. Talha. 2000. Seed rates and sowing dates effect on the performance of wheat Bakhatawar-92. Pak. J. Biol. Sci. 3: 1409-1411. https://doi.org/10.3923/ pjbs.2000.1409.1411

Barker, A.V. and D.J. Pilbeam. 2007. Hand book of plant nutrition. CRC press, Boca Raton, Florida, USA.

Basit, A., M.I. Faisal, A. Gul, A.K. Jaffar and N. Ahmad. 2005. Studies of nitrogen use efficiency in wheat (Triticum aestivum L.) by split application at different growth stages. App. Em. Sci. 1(2): 39-42.

Buttar, G.S., H.S. Sidhu, V. Singh, M.L. Jat, R. Gupta, Yadvinder-Singh and B. Singh. 2013. Relay planting of wheat in cotton: An innovative technology for enhancing productivity and profitability of wheat in cottonwheat production system of South Asia. Exp. 
Agric. 49(1): 19-30. https://doi.org/10.1017/ S0014479712001032

Cassman, K.G., A. Dobermann and D.T. Walters. 2002. Agroecosystems, nitrogen use efficiency, and nitrogen management. Ambio J. Hum. Environ., 31(2): 132-140. https://doi. org/10.1579/0044-7447-31.2.132

CIMMYT, 1988. From agronomic data to farmers recommendations: An economics training manual. Completely revised edition. Mexico DF.

Haile, D., D. Nigussie and A. Ayana.2012. Nitrogen use efficiency of bread wheat: effects of nitrogen rate and time of application. J. Soil Sci. Plant Nutr. 12(3): 389-409.

Khan, M.B. and A. Khaliq. 2005. Production of winter cereals as relay crops by surface seeding in cotton based cropping system. J. Res. Sci., 16(2): 79-86.

Malghani, A.L., A.U. Malik, A. Sattar, F. Hussain, G. Abbas and J. Hussain. 2010. Response of growth and yield of wheat to NPK fertilizer. Sci. Int., 24: 185-189.

Mengel,K.and E.A.Kirkby.2001.Principles of plant nutrition. Kluwer Academic Publishers ( $5^{\text {th }}$ ed.) Dordrecht, Boston, London, Netherlands.

Naveed, K., M.A. Khan, M.S. Baloch, N. Khan and M.A. Nadim. 2013. Effect of time of nitrogen application on morphological and physiological attributes of dual-purpose wheat. Pak. J. Bot., 45(4): 1299-1305.

Niamatullah, M., M. Khan, M.Q. Khan, M. Sadiq, K.U. Zaman, C.S. Hayat and S. Rehman. 2011. Impact of NPK applications on the number of productive tillers and cost benefit analysis of wheat in hill-torrent irrigated area of D. I. Khan division, Khyber Pakhtoonkhwa. J. Anim. Plant Sci., 21(2): 211-214.

Nielsen, H.H., P. Ambus and E.S. Jensen. 2001. Interspecific competition, $\mathrm{N}$ use and interference with weeds in pea-barley intercropping. Field Crops Res., 70(2): 101-109. https://doi. org/10.1016/S0378-4290(01)00126-5

Rahman, M.A., M.A.Z.Sarker,M.F.Amin, A.H.S. Jahan and M.M. Akhter. 2011. Yield response and nitrogen use efficiency of wheat under different doses and split application of nitrogen fertilizer. Bangladesh J. Agric. Res., 36(2): 231240. https://doi.org/10.3329/bjar.v36i2.9249

Rajpar, I., Y.M. Khanif, O.H. Ahmed, N.B. Sial and M.A. Korejo. 2006. Effect of source and time of application of phosphatic fertilizers on wheat (Triticum aestivium L.). Am. Euras. J. Agric. Environ. Sci., 1(2): 83-85.

Ros, C.O.D., R.L. Salet, R.L. Porn and J.N.C. Machado. 2003. Effects of fertilization methods on soil nitrogen availability for wheat and corn production. Ciência Rural Santa Maria, 33: 799-804. https://doi.org/10.1590/S010384782003000500002

Sankaran, N., S. Meena and N. Sakthivel. 2005. Input management in maize. Madras Agric. J., 92: 464-468.

Shah, W.A., H.U. Khan, S. Anwar and K. Nawab. 2011. Yield and yield components of wheat as affected by different seed rates and nitrogen levels. Sarhad J. Agric., 27(1): 17-25.

Singh, K.N. and D.P. Sharma. 2001. Response of wheat to nitrogen and potassium in saline soils. Exp. Agric., 37(3): 417-427. https://doi. org/10.1017/S0014479701003118

Smith, C.W. and J.J. Varvil. 1982. Double cropping cotton and wheat. Agron. J., 74(5): 862-865. https://doi.org/10.2134/agronj1982.00021962 007400050022x

SSSP, 1994. Efficient use of plant nutrients. In: Proceedings of $4^{\text {th }}$ National Congress of Soil Science, Islamabad, Soil Sci. Soc. Pak. pp. 3.

Steel, R.G.D., J.H. Torrie and D.A. Dickey. 1997. Principles and Procedures of Statistics: A Biometrical Approach. 3rd ed. McGraw Hill Book Co. Inc. New York. pp. 400-428. https:// doi.org/10.1016/j.fcr.2006.07.010

Ugarte, C., D.F. Calderini and G.A. Slafer. 2007. Grain weight and grain number responsiveness to pre-anthesis temperature in wheat, barley and triticale. Field Crops Res. 100(2-3): 240248.

Wen-Xia, X., W. Guang-Huo, Z. Qi-Chun and G. Hai-Chao. 2007. Effects of nitrogen fertilization strategies on nitrogen use efficiency in physiology, recovery, and agronomy and redistribution of dry matter accumulation and nitrogen accumulation in two typical rice cultivars in Zhejiang, China. J. Zhejiang Univ. Sci., 89(3): 208-216. https://doi.org/10.1631/ jzus.2007.B0208

Willey, R.W., 1990. Resource use in intercropping systems. Agric. Water Manage., 17(1-3): 215-231. https://doi.org/10.1016/03783774(90)90069-B

Woolfolk, C.W., W.R. Raun, G.V. Johnson, W.E. 
Thomason, R.W. Mullen, K.J. Wynn and K.W. Freeman. 2002. Influence of late-season foliar nitrogen applications on yield and grain nitrogen in winter wheat. Agron. J., 94(3): 429434. https://doi.org/10.2134/agronj2002.4290

Yaseen, G., I. Mehboob, N. Ahmad and M. Yaseen. 2005. Effect of phosphorus application time on yield and $\mathrm{P}$ use efficiency by wheat crop. J. Agric. Res., 43(1): 1-7.

Zhang, F., J. Shen, L. Li and X. Liu. 2004. An overview of rhizosphere processes related with plant nutrition in major cropping systems in China. Plant Soil, 260(1-2): 89-99. https://doi. org/10.1023/B:PLSO.0000030192.15621.20

Zhang, L.Z., W.V.D. Werf, L. Bastiaans, S.
Zhang, B. Li and J.H.J. Spiertz. 2008a. Light interception and utilization in relay intercrops of wheat and cotton. Field Crops Res., 107(1): 2942. https://doi.org/10.1016/j.fcr.2007.12.014

Zhang, L.Z., J.H.J. Spiertz, S.P. Zhang, B. Li and W. Van der Werf. 2008b. Nitrogen economy in relay intercropping systems of wheat and cotton. Plant Soil, 303(1-2): 55-68. https://doi. org/10.1007/s11104-007-9442-y

Zhang, L.Z., W.V.D. Werf, S. Zhang, B. Li and J.H.J. Spiertz. 2007. Growth, yield and quality of wheat and cotton in relay strip intercropping systems. Field Crops Res., 103(3): 178-188. https://doi.org/10.1016/j.fcr.2007.06.002 